\title{
ANALISIS PENGARUH MANAJEMEN MODAL KERJA TERHADAP KEMAMPUAN PENCAPAIAN LABA PADA USAHA DAGANG (STUDI KASUS PADA TOKO DI SORONG)
}

\author{
Wisang Candra Bintari \\ Dosen Fakultas FISIP Universitas Muhammadiyah Sorong
}

Diterima:10 Oktober 2016. Disetujui:20 November 2016. Dipublikasikan:1 Desember 2016

\begin{abstract}
Abstrak
Penelitian ini berfokus pada faktor-faktor yang mempengaruhi pencapaian laba masa depan. Hasil uji dan olah data menerangkan hal-hal sebagai berikut hipotesis pertama (Hipotesis 1) yang mengatakan bahwa variable kas $\left(\mathrm{X}_{1}\right)$, variable piutang $\left(\mathrm{X}_{2}\right)$ serta variable persediaan $\left(\mathrm{X}_{3}\right)$ secara bersama-sama mempunyai pengaruh terhadap variable laba $(\mathrm{Y})$ dapat dibuktikan pada Uji $\mathrm{F}$ sehingga dapat diterima dan terbukti. Penilaian keyakinan hipotesis tersebut didasarkan pada hasil uji bahwa nilai $\mathrm{F}$ hitung adalah sebesar 7,298 dengan tingkat signifikan 0,001 atau sebesar $0,1 \%$.Pada sisi lain nilai $F$ tabel dengan variable bebas sebanyak 3 variabel dan sampel sejumlah 36 obyek pengamatan adalah 2,342. Jika dibandingkan maka dinyatakan bahwa nilai $\mathrm{F}$ hitung > nilai $\mathrm{F}$ tabel yang berarti secara simultan ketiga variable bebas mempunyai pengaruh yang signifikan terhadap laba. Hipotesis kedua (Hipotesis 2) yang mengatakan bahwa secara terpisah (Parsial) variable-variabel kas $\left(\mathrm{X}_{1}\right)$, piutang $\left(\mathrm{X}_{2}\right)$ dan persediaan $\left(\mathrm{X}_{3}\right)$ tidak terbukti memberikan pengaruh secara parsial terhadap variable $(\mathrm{Y})$ pencapaian laba. Penarikan keyakinan hipotesis tersebut didasarkan pada hal-hal sebagai berikut Variable kas $\left(\mathrm{X}_{1}\right)$, mempunyai nilai 0,000 secara parsial variable ini tidak terbukti memberikan pengaruh terhadap variable $(\mathrm{Y})$ pencapaian laba. Variable piutang $\left(\mathrm{X}_{2}\right)$, memberikan pengaruh terhadap pencapaian laba $(\mathrm{Y})$ sebesar 0,011 . Variabel persediaan $\left(\mathrm{X}_{3}\right)$, mempunyai nilai -0,531 terhadap pencapain laba. Adapun kontribusi pengaruh masing-masing variable bebas terhadap variable terikat dalam penelitian ini dapat dijabarkan sebagai berikut Variable kas $\left(\mathrm{X}_{1}\right)$ memberikan pengaruh 0,000 terhadap pencapaian laba (Y). Pengertian yang terkandung adalah apabila toko Iqra mengalami peningkatan kas 0,000 atau $0 \%$ dari tahun lalu, maka perlu usaha peningkatan penjualan supaya kas perusahaan lebih meningkat. Variable piutang memberikan pengaruh terhadap laba (Y) sebesar 0,011 atau 1,1\%. Makna yang terkandung adalah apabila perusahaan menambah jumlah piutangnya sampai sebesar $1,1 \%$, maka pada saat dan periode yang sama tersebut membuka peluang bagi toko Iqra untuk meningkatkan laba sampai $100 \%$ dibandingkan dengan periode sebelumnya Variable persediaan $\left(\mathrm{X}_{3}\right)$-0,531 menyatakan bahwa setiap penambahan (karena tanda -) akan mengurangi laba sebesar -0,531. Hipotesis ketiga (Hipotesis 3) yaitu bahwa persediaan mempunyai pengaruh dominan diantara variable-variabel kas $\left(X_{1}\right)$, piutang $\left(X_{2}\right)$ terhadap kemampuan pencapaian laba ternyata tidak terbukti. Penolakan hipotesis ini berdasarkan hasil uji sebagai berikut:variable $\left(\mathrm{X}_{1}\right)$ yaitu variable kas memiliki nilai yang dominan kedua setelah piutang dalam upaya pencapaian laba pada toko Iqra. Variable $\left(\mathrm{X}_{2}\right)$ yaitu ternyata memiliki nilai yang dominan dalam upaya kemampuan pencapaian laba pada toko Iqra. Variable $\left(\mathrm{X}_{3}\right)$ yaitu variable persediaan yang merupakan faktor yang paling rendah dominannya dalam kemampuan pencapaian laba pada toko Iqra.
\end{abstract}


Kata Kunci: Analisis, Manajemen, Modal, Kerja, Laba,

\section{Pendahuluan}

Modal kerja (working capital) merepresentasikan dana-dana temporer perusahaan, modal kerja tersebut digunakan untuk mendukung opersional perusahaan dalam jangka pendek. Akuntan menyebutkan modal kerja sebagai asset lancar dikurangi kewajiban lancar. Kebutuhan akan modal kerja meningkat dikarenakan adanya ketidakseimbangan dalam arus masuk dan keluar dari bisnis akibat fluktuasi musiman yang terjadi. Penjualan kredit, penjualan musiman, atau perubahan permintaan yang tidak dapat diramalkan akan menciptakan fluktuasi dalam arus kas perusahaan kecil.

Namun tidak dapat dihindari, kadang muncul masalah salah satunya kapan dan faktor apa yang harus menjadi perhatian dan fokus utama untuk dikembangkan agar pencapaian laba tersebut dapat berjalan lancar dan stabil dan berkelanjutan, karena salah dalam menentukan titik prioritas kebijakan, maka yang didapatkan kelak bukan keuntungan justru kerugian.Peran manajemen dan sumber daya yang lain sangat terkait untuk usaha menciptakan laba, bukan tanggung jawab pemilik saja, melainkan semua yang terkait dengan usaha itu harus terlibat didalamnya. Penganggaran modal harus diintergrasikan dengan perencanaan strategis karena investasi yang berlebihan atau investasi yang tidak mencukupi akan mempunyai konsekuensi yang serius terhadap masa depan perusahaan. Jika perusahaan akan menanggung beban berat yang tidak perlu. Jika yang ditanamkan tidak cukup, perusahaan akan mempunyai kapasitas yang tidak memadai dan dapat kehilangan sebagian pangsa pasarnya untuk direbut perusahaan-perusahaan saingan. Mendapatkan kembali konsumen yang hilang adalah sulit dan mahal.

Tujuan penelitian ini adalah sebagai beriku mengetahui pengaruh secara simultan antara kas, piutang, dan persediaan terhadap pencapaian laba pada usaha dagang (toko di Sorong). Mengetahui pengaruh secara partial antara kas, piutang dan persediaan terhadap pencapaian laba pada usaha dagang (toko Di Sorong). Dan mengetahui faktor yang paling dominan berpengaruh dalam upaya pencapaian laba pada usaha dagang (toko di Sorong) diantaranya kas, piutang dan persediaan.

\section{METODOLOGI PENELITIAN}

\section{Definisi Konsep dan Operasional Variabel}

Untuk memperjelas arti variabelvariabel yang digunakan dalam penelitian ini, definisi operasional masing-masing variabel akan diuraikan sebagai berikut:

\section{a. Kas (X1)}

Merupakan bentuk aktiva yang paling likuid, yang bisa digunakan untuk memenuhi kewajiban financial perusahaan. Untuk mengetahui dan menghitung perputaran kas dapat digunakan rumus sebagai berikut:

$\begin{aligned} \text { Perputaran Kas } & =\frac{\text { Penjualan Tunai }}{\text { Kas rata }- \text { rata }} \\ \text { Rata-rata kas } & =\frac{\text { Kas awal }+ \text { Kas akhir }}{2}\end{aligned}$

b. Piutang (X2)

Merupakan pertumbuhan investasi dalam bentuk penyaluran kredit yang realisasinya dalam bentuk penjualan kredit. Setiap analisis ekonomi yang menyangkut 
perbandingan antara manfaat dan pengorbanan. Untuk mengetahui penentuan jumlah kebutuhan modal kerja berdasarkan perputaran modal kerja, salah satunya piutang dapat dihitung dengan rumus sebagai berikut:

Perputaran Piutang $=\frac{\text { Penjualan kredit }}{\text { Piutang rata }- \text { rata }}$

Rata - Rata Piutang $=$ $\underline{\text { Piutang awal +Piutang akhir }}$

\section{c. Persediaan (X3)}

Persediaan barang dagang (merchandise inventory) adalah barangbarang yang dimiliki perusahaan untuk dijual kembali. Angka perputaran persediaan menunjukkan berapa kali perusahaan mengganti persediaannya dalam satu tahun. Jangka waktu penjualan dalam persediaan menunjukkan berapa hari, secara rata-rata, perusahaan menyimpan persediaannya sebelum terjual. Makin pendek jangka waktu ini, makin baik bagi perusahaan. Untuk menggambarkan keterangan diatas dapat dilihat dengan rumus:

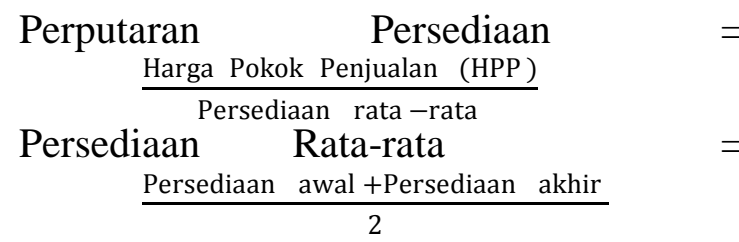

\section{d. Profitabilitas (Y)}

Merupakan kemampuan modal perusahaan yang diinvestasikan dalam aktiva untuk menghasilkan keuntungan netto, merupakan perbandingan antara keuntungan bersih setelah pajak dengan total aktiva rata-rata (ROA), menggunakan skala ratio dan dinyatakan dalam persentase. Dapat dirumuskan sebagai berikut:

\section{Populasi dan Sampel}

Populasi yang digunakan dalam penelitian ini adalah Laporan Keuangan Toko Iqra Sorong. Sampel tehnik penentuan sample pada penelitian ini menggunakan metode purpose sampling, yaitu tehnik sampling dengan mendasarkan pada tujuan tertentu. Sampel penelitian yang terambil adalah Laporan bulanan Toko Iqra periode tahun 2008-2010.

\section{Jenis dan Sumber Data}

Jenis data yang digunakan dalam penelitian ini data sekunder. Data yang dibutuhkan adalah laporan keuangan bulanan tahun buku 2008 - 2010. Sumber data dalam penelitian ini diperoleh dari usaha dagang toko Iqra.

\section{Pengumpulan Data.}

Didalam penelitian yang kami lakukan maka kami mengumpulkan datadata yang sangat dibutuhkan di dalam menyelesaikan tesis ini. Adapun cara pengumpulan data yang digunakan adalah sebagai berikut : Data Primer yaitu data yang diperoleh melalui penelitian langsung di lapangan berdasarkan obyek yang akan diteliti. Adapun cara pengumpulan data yang digunakan adalah sebagai berikut: cara interview yaitu suatu bentuk penelitian dimana untuk mendapatkan data diadakan suatu wawancara pada pihakpihak yang berkepentingan dengan kegiatan yang berhubungan analisis pengaruh manajemen modal kerja terhadap kemampuan pencapaian laba. Data Skunder yaitu data yang diperoleh melalui kepustakaan serta buku atau literatureliterature yang berhubungan dengan obyek penelitian .

5. Dokumentasi yaitu mempelajari dokumen-dokumen yang berupa laporan keuangan bulanan toko Iqra.

\section{Teknik Analisis}

Penelitian ini tergolong dalam analisis kuantitatif yaitu suatu tehnik 
analisa dimana data-data yang berbentuk angka-angka akan dianalisis dengan cara melakukan penghitungan dengan menggunkan metode statistik analisis regresi berganda yang dapat dinyatakan sebagai berikut:

$\mathrm{Y}=\mathbf{B 0}+\mathbf{B 1 X} \mathbf{X}+\mathbf{B 2 X} \mathbf{2}+\mathbf{B 3 X} 3+\mathrm{ei}$

Keterangan:

$$
\begin{array}{ll}
\mathrm{Y} & =\text { Profitabilitas } \\
\mathrm{X} 1 & =\text { Kas } \\
\mathrm{X} 2 & =\text { Piutang } \\
\mathrm{X} 3 \quad=\text { Persediaan } \\
\text { Bo } \quad= & \\
\text { (intercept) } & \\
\text { B1,ß2,ß3 } & =\text { Koefisien regresi } \\
\text { ei } & =
\end{array}
$$

\section{Uji Hipotesis}

Prosedur untuk pengujian statistiknya dengan langkah-langkah sebagai berikut:

\section{a. Uji F (Uji Simultan F)}

Uji statistik $F$ pada dasarnya menunjukkan apakah semua variabel bebas yang dimasukkan dalam model mempunyai pengaruh secara bersamasama terhadap variabel terikat, atau variabel independen terhadap variabel dependen. Langkah-langkahnya sebagai berikut:

a. Perumusan Hipotesis

HO: $\beta 1=\beta 2=\beta 3=0 \quad\{$ Kas (X1), Piutang (X2), dan Persediaan(X3), tidak berpengaruh terhadap Profitabilitas (Y)\}.

Нi: $\beta 1 \neq \beta 2 \neq \beta 3 \neq 0 \quad\{\operatorname{Kas}(\mathrm{X} 1)$, Piutang (Kas X2), dan Persediaan(X3), tidak berpengaruh terhadap Profitabilitas (Y)\}.

b. Menentukan tingkat signifikan yaitu $\alpha$ $=5 \%$ (tingkat kesalahan yang dapat ditoleransi) dengan derajat bebas (n-k1), dimana $\mathrm{n}=$ jumlah pengamatan dan $\mathrm{k}=$ jumlah variabel independen. c. Menentukan nilai F hitung menggunakan rumus:

$$
\text { Fhitung }=\frac{\mathbf{R}^{2} /(\mathbf{k}-\mathbf{1})}{\left(\mathbf{1}-\mathbf{R}^{2}\right) /(\mathbf{n}-\mathbf{k}-\mathbf{1})}
$$

Dimana :

$$
\begin{array}{ll}
\text { Fhitung } & =\text { hasil perhitungan } \\
\mathrm{R}^{2} & =\text { koefisien determinasi } \\
\mathrm{n} & =\text { jumlah sampel } \\
\mathrm{k} & =\text { jumlah variabel }
\end{array}
$$

independent.

d. Menentukan kriteria

1. $\mathrm{HO}=$ ditolak dan Hi diterima jika Fhitung $>$ Ftabel

Artinya, variabel independen secara simultan mempunyai pengaruh yang signifikan terhadap variabel dependen.

2. $\mathrm{HO}=$ diterima dan $\mathrm{Hi}$ ditolak jika Fhitung $\leq$ Ftabel

Artinya,variabel independen secara simultan tidak mempunyai pengaruh yang signifikan terhadap variabel dependen .

\section{b. Uji t (Uji Parsial)}

Uji t digunakan untuk mengetahui pengaruh masing-masing variabel independen terhadap variabel dependen secara sendiri-sendiri (parsial). Adapun langkah-langkahnya adalah sebagai berikut

a. $\mathrm{H}: \beta 1, \beta 2$, dan $\beta 3=0$ tidak terdapat pengaruh antara $\mathrm{X} 1, \mathrm{X} 2, \mathrm{X} 3$ terhadap $\mathrm{Y}$ $\mathrm{H}: \beta 1, \beta 2$, dan $\beta 3 \neq 0$ terdapat pengaruh $\mathrm{X} 1, \mathrm{X} 2, \mathrm{X} 3$ terhadap $\mathrm{Y}$.

b. Menghitung level of signifikan ( $\alpha$ ) sebesar $0,05 \%$ dengan (tingkat kesalahan yang dapat ditoleransi), dengan derajat bebas (n-k1), dimana $n=$ jumlah pengamatan dan $\mathrm{k}=$ jumlah variabel.

c. Menentukan nilai t hitung

$$
\text { thitung }=\frac{\mathbf{b j}}{\operatorname{Se}(\mathbf{b j})}
$$


Dimana :

$$
\begin{aligned}
& \text { t hitung = hasil perhitungan } \\
& \mathrm{bj}=\text { koefesien regresi } \\
& \mathrm{Se}=\text { standart error. }
\end{aligned}
$$

d. Menentukan Kriteria

1. Ho = ditolak jika $\mathrm{t}$ hitung $<-\mathrm{t}$ tabel atau > thitung $>\quad \mathrm{t}$ tabel

Artinya, variabel independen secara parsial mempengaruhi variabel dependen.

2. Ho $=$ diterima jika $-\mathrm{t}$ tabel $\leq$ thitung $\leq \mathrm{t}$ tabel

Artinya, variabel independen secara parsial tidak mempengaruhi variabel dependen.

\section{c. Asumsi Klasik}

Persamaan regresi tersebut harus bersifat BLUE (Best Linear Unbiased Estimator), artinya pengambilan keputusan uji $\mathrm{F}$ dan uji t tidak boleh bias. Untuk menghasilkan keputusan yang BLUE maka harus dipenuhi diantaranya empat asumsi dasar yang tidak boleh dilanggar oleh regresi linier yaitu :

1. Tidak boleh ada multikolinieritas.

2. Tidak boleh ada heterokedastisitas.

3. Tidak boleh ada autokrelasi.

Apabila salah satu dari keempat asumsi dasar tersebut dilanggar maka persamaan regresi yang diperoleh tidak lagi bersifat BLUE sehingga pengambilan keputusan melalui:

\section{Autokorelasi}

Autokorelasi muncul karena observasi yang berurutan sepanjang waktu berkaitan satu sama lain (Hanke \& Reiitsch,1998:360). Masalah ini timbul karena residual tidak bebas dari satu observasi ke observasi lainnya. Hal ini disebabkan karena "gangguan" pada seorang individu/kelompok yang sama pada periode berikutnya; pada data kerat silang (cross section), masalah autokorelasi relatif jarang terjadi karena gangguan pada observasi yang berbeda berasal dari individu/kelompok yang berbeda (Mudrajat Kuncoro,2007:90). Autokorelasi dapat didefinisikan sebagai korelasi antar observasi yang diurutkan berdasarkan urut waktu (data time series) atau data yang diambil pada waktu tertentu. Jadi dalam model regresi linear diasumsikan tidak terjadi gejala autokorelasi, artinya residual (Y observasi - Y prediksi) pada waktu ke t(et) tidak boleh ada hubungan dengan nilai residual periode sebelumnya. Untuk mengetahui ada tidaknya gejala autokorelasi maka perlu dilihat tabel Durbin Watson. Jika nilai Durbin Wastson lebih kecil dibandingkan nilai teoritisnya menunjukkan adanya autokorelasi. (Gujarati:201). Perlu dicatat bahwa uji Durbin Winston ini hanya digunakan untuk autokorelasi tingkat satu (first order autocorrelation) dan mensyaratkan adanya intercipt dalam model regresi dan tidak ada variabel lagi diantara variabel penjelas. Hipotesis yang diuji adalah:

Ho $: p=0$ (baca: hipotesis nolnya adalah tidak ada autokorelasi)

Ho : p > 0 (baca: hipotesis alternatifnya adalah ada autokorelasi positif).

Keputusan ada tidaknya autokorelasi adalah:

a. Bila nilai DW lebih besar daripada batas atas (upperbound, U), maka koefesien autokorelasi sama dengan nol. Artinya, tidak ada autokorelasi positif.

b. Bila nilai DW lebih rendah daripada batas bawah (lowerbound,L), koefesien autokorelasi lebih besar daripada nol. Artinya ada autokorelasi positif'

c. Bila nilai DW terletak diantara batas atas dan bawah, maka tidak dapat disimpulkan.

\section{Mulitikolinear}

Multikorelasi berarti adanya hubungan linear yang sempurna atau pasti 
diantara atau sejumlah variabel yang menjelaskan dari model regresi. Identifikasi secara statistik ada atau tidaknya gejala multikolinear dapat dilakukan dengan menghitung VIF (varience inflation factor) dengan menggunakan rumus:

VIF $=$

$1 /$ Tolerance

VIF (varience inflation factor) menyatakan tingkat "pembengkakan" varians. Apabila VIF lebih besar dari 10, hal ini berarti terdapat multikolinear pada persamaan regresi. (Gujarai 157).

\section{Heteroskedastisitas}

Penyebaran variabel bebas adalah tidak konstan (berbeda) untuk setiap nilai tertentu variabel. Hal ini bisa diidentifikasi dengan cara menghitung korelasi Rank Sperman antara residual dengan seluruh variabel bebas atau yang menjelaskan (Gujarati:177)

$$
\begin{aligned}
& \begin{array}{l}
\text { Rumus } \\
\text { Sperman, }
\end{array} \\
& \begin{array}{l}
\text { Rumus } \\
\text { Sperman, }
\end{array} \\
& \mathbf{R s}=\frac{1-\mathbf{b} \sum d i^{2}}{\mathrm{n}-\left(\mathrm{n}^{2}-1\right)}
\end{aligned}
$$

Keterangan :$$
\text { Di }=\text { perbedaan dalam rank }
$$
antara residual dengan variabel bebas ke $\mathrm{i}$$$
\mathrm{n} \text { = banyaknya data. }
$$

\section{HASIL PENELITIAN DAN}

\section{PEMBAHASAN}

\section{A. Deskripsi Hasil Penelitian}

Dalam melakukan olah penelitian dan agar terjadi pemahaman mengenai alur pemikiran yang sama terhadap hasil penelitian, maka peneliti melakukan analisa data yang dimulai dari analisis deskriptif terhadap variable penelitian. Analisis deskriptif variable penelitian ini dimaksudkan untuk memberikan gambaran tentang keberadaan data penelitian yang

Table 1.Variable Perputaran Kas $\left(\mathrm{X}_{1}\right)$ Toko Iqra Sorong Tahun 2008-2010 penelitian berasal dari data sekunder Toko Iqra pada periode 2008 - 2010. Setelah melakukan analisis deskriptif terhadap variable penelitian, olah data berlanjut pada pengujian asumsi klasik. Pengujian ini dimaksudkan untuk melihat ada tidaknya kondisi bias pada variablevariabel penelitian serta kemungkinan untuk dapatnya dilakukan pengujian regresi berganda. Olah data penelitian terakhir adalah melakukan uji regresi berganda. Pengujian ini dimaksudkan untuk melihat besaran pengaruh variablevariabel bebas terhadap variable terikatnya.

\section{Analisis deskriptif variable penelitian}

\section{a. Variable Kas $\left(\mathbf{X}_{1}\right)$}

Kas bagi perusahaan merupakan asset utama yang dapat dimanfaatkan dan dipergunakan setiap saat guna kelancaran operasional. Kas juga merupakan asset yang harus dijaga dan diperhitungkan serta dianalisis dengan cermat agar setiap pemanfaatan kas baik kas masuk maupun kas keluar dapat menghasilkan laba bagi perusahaan. Kas yang dimiliki oleh perusahaan adalah baik itu uang dalam perusahaan maupun yang disimpan di bank atas nama perusahaan. Manajemen kas dalam perusahaan dagang Iqra perlu ditingkatkan, karena kesalahan dalam mengelola kas akan membawa dampak yang fatal bagi perusahaan, baik jangka pendek maupun jangka panjang. Analisis posisi kas dilakukan dengan menghitung rata-rata kas setiap periode bulanan sehingga dapat diketahui perputaran kas setiap bulan dalam satu periode yang sama. Untuk mengetahui berapa kali perputaran kas periode 2008-2010 dapat dilihat pada tabel berikut ini : 
Jurnal Noken 2(1) 40-57 2016

\begin{tabular}{ccccccc}
\hline & \multicolumn{2}{c}{2008} & \multicolumn{2}{c}{2009} & \multicolumn{2}{c}{2010} \\
\cline { 2 - 7 }$\approx$ & Total & Mean & Total & Mean & Total & Mean \\
& 811,531 & 67,628 & 521,917 & 43,493 & 448,456 & 37,371
\end{tabular}

Dengan melihat table tesebut tampak jika pada tahun 2008 akumulasi kas sebesar $\operatorname{Rp} 233.096 .950,00$ atau sebesar Rp 19.424.745,8333 per bulannya dan rata-rata perputaran per bulannya 69,9 kali. Pada tahun 2009 akumulasi kas adalah sebesar $\mathrm{Rp}$ 216.672.400,00 atau sebesar Rp 18.056.033 per bulannya dan rata-rata perputaran per bulannya 43,5 kali terjadi penurunan disbanding tahun 2008. Sedangkan tahun 2010 akumulasi kas Rp 254.045.000,00 atau sebesar $\mathrm{Rp}$ 21.170.416,00 per bulannya dan rata-rata perputaran per bulannya 37,4 kali.

\section{b. Variable Piutang $\left(\mathbf{X}_{2}\right)$}

Piutang dalam hal ini, piutang usaha perusahaan dagang Iqra merupakan asset perusahaan yang timbul dari transaksi penjualan kredit. Strategi penjualan secara kredit ini dengan tujuan meningkatkan laba perusahaan. Keputusan tentang berapa banyak piutang akhirnya akan dimiliki perusahaan akan tergantung sebagian besar pada bagian pemasaran. Meskipun demikian, dampak keputusan tersebut akan terasa pada bagian keuangan, paling tidak yang menyangkut masalah pendanaan. Dengan demikian, Nampak bahwa keputusan-keputusan keuangan bukan

Table .2. Variable Perputaran Piutang $\left(\mathrm{X}_{2}\right)$ Toko Iqra Sorong Tahun 2008-2010

\begin{tabular}{|c|c|c|c|c|c|c|}
\hline \multirow{3}{*}{ 泀 } & \multicolumn{2}{|c|}{2008} & \multicolumn{2}{|c|}{2009} & \multicolumn{2}{|c|}{2010} \\
\hline & Total & Mean & Total & Mean & Total & Mean \\
\hline & 12,759 & 1,06325 & 48,692 & 4,05767 & 12,203 & 1,017 \\
\hline
\end{tabular}

Dengan mendasarkan pada tabel 2. dapat dijabarkan hal-hal sebagai berikut :

a. Pada tahun 2008 piutang dagang (usaha Toko Iqra) sebesar Rp 4.328.127.960,2 (pertahun) atau $\mathrm{Rp}$ 360.677.330,016 setiap bulannya. hanya terbatas dilakukan oleh bagian keuangan saja. Analisis ekonomi tentang piutang pada dasarnya mencoba membandingkan manfaat dan pengorbanan yang timbul karena memiliki piutang. Karena yang itulah diperlukan identifikasi manfaat dan pengorbanan tersebut. Jumlah piutang yang dimiliki perusahaan, disamping ditentukan oleh penjualan, persyaratan penjualan dan standar kredit juga dipengaruhi oleh manajemen (pengumpulan) piutangnya. Pencatatan piutang yang tidak baik, karyawan yang kurang, merupakan factor-faktor yang menyebabkan mengapa rata-rata piutang meningkat, membuat perputaran piutang lebih rendah dari standar persyaratan penjualan. Analisis untuk mengenali calon pembeli yang baik dan yang buruk dapat dilakukan dengan berbagai cara. Salah satu cara yang mungkin dipergunakan adalah dengan menggunakan analisis diskrimiman. Dalam setiap analisis untuk pengambilan keputusan membuat trade-off antara menolak atau mengabulkan permohonan.

Tingkat perputaran piutang dapat dilihat pada tabel .2 berikut ini :
Dengan tingkat perputaran 12,759 per tahunnya atau 1,06 kali perputarannya per bulan.

b. Pada tahun 2009 piutang dagang (usaha Toko Iqra) sebesar Rp 2.446.501.994,2 (pertahun) atau $\mathrm{Rp}$ 
203.875.166,184 setiap bulannya. Dan tingkat perputarannya 48,692 kali pertahun atau 4,06 kali perbulan.

c. Pada tahun 2010 piutang dagang (usaha Toko Iqra) sebesar Rp 1.042.932.368,8 pertahun atau $\mathrm{Rp}$ 86.911.030,7333 per bulannya. Dengan tingkat perputaran pertahun 12,203 kali atau 1,017 kali perputarannya per bulan.

Secara general rata-rata perputaran dapat disimpulkan semakin cepat perputaran piutang dapat dijadikan uang tunai maka akan meningkatkan kemampuan pencapaian laba perusahaan.

\section{c. Variable Persediaan $\left(\mathbf{X}_{3}\right)$}

Perusahaan memiliki persediaan dengan maksud untuk menjaga kelancaran operasionalnya. Bagi perusahaan dagang, persediaan barang dagangan memungkinkan perusahaan memenuhi permintaan pembeli. Meskipun demikian tidak berarti perusahaan harus menyediakan persediaan sebanyakbanyaknya untuk maksud tersebut.Persediaan yang tinggi menunjukkan perusahaan memenuhi permintaan yang mendadak meskipun demikian persediaan yang tinggi akan menyebabkan perusahaan memerlukan modal kerja yang makin besar pula. Apabila perusahaan mampu memprediksi dengan cepat kebutuhan akan barang dagangannya, maka perusahaan mampu menyediakan stock barang tepat pada waktunya dengan jumlah yang diperlukan. Persediaan yang besar akan menimbulkan keluwesan yang lebih besar bagi perusahaan, tetapi akan menimbulkan biaya besar pula, sebaliknya persediaan yang kecil akan menghemat biaya tetapi menimbulkan gangguan penjualan tingkat perputaran persediaan dapat dilihat pada tabel 3 sebagai berikut :

\begin{tabular}{ccc} 
Table 3.Variable Perputaran Persediaan $\left(X_{3}\right)$ Toko Iqra Sorong Tahun 2008-2010 \\
\hline-
\end{tabular}

\begin{tabular}{|c|c|c|c|c|c|c|}
\hline \multirow{3}{*}{ 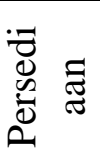 } & \multicolumn{2}{|c|}{2008} & \multicolumn{2}{|c|}{2009} & \multicolumn{2}{|c|}{2010} \\
\hline & Total & Mean & Total & Mean & Total & Mean \\
\hline & 10,163 & 0,847 & 12,547 & 1,046 & 10,98 & 0,915 \\
\hline
\end{tabular}

Tingkat perputaran persediaan (inventory tuinover) yang ditujukan pada tabel diatas :

a. Pada tahun 2008 tingkat perputaran persediaan 10,163 kali pertahun atau rata-rata 0,847 per bulannya.

b. Pada tahun 2009 tingkat perputaran persediaan pertahun 12,547 kali atau rata-rata 1,046 perbulan, terjadi peningkatan jika disbandingkan dengan tahun 2008.

c. Sedangkan tahun 2010 perputaran persediaan pertahun 10,98 kali atau rata-rata perbulan 0,915 , terjadi penurunan jika dibandingkan dengan tahun sebelumnya.

Dari data diatas dapat dsimpulkan semakin tinggi tingkat perputaran persediaan tersebut maka jumlah modal kerja yang dibutuhkan (terutama yang harus diinvestasikan dalam persediaan) semakin rendah. Untuk dapat mencapai tingkat perputaran yang tinggi, maka harus diadakan perencanaan dan pengawasan persediaan secara teratur dan efisien. Semakin cepat atau semakin tinggi tingkat perputaran akan memperkecil resiko terhadap kerugian yang disebabkan karena penurunan harga atau karena perubahan selera konsumen. Disamping itu akan menghemat ongkos penyimpanan dan pemeliharaan terhadap persediaan tersebut.
d. Variable
(Y)
Pencapaian Laba (Profitabilitas)
Kemampuan pencapaian laba merupakan fokus usaha dagang Iqra, 
karena variable ini akan menggambarkan kemampuan operasional dalam menciptakan laba yang menunjukkan kinerja perusahaan dari sisi keuangan. Profitabilitas adalah kemampuan perusahaan memperoleh laba dalam hubungannya dengan penjualan, total aktiva maupun modal sendiri. Oleh sebab itu guna mencapai laba optimal, maka perusahaan harus melakukan analisis perencanaan laba. Untuk menggambarkan kondisi laba pada usaha dagang Iqra, salah satu analisis yang dipergunakan adalah ROA (Return on average assets) yaitu laba bersih terhadap total aktiva rata-rata dalam periode yang sama. Tabel 4 menggambarkan kondisi kemampuan pencapaian laba (profitabilitas).

\begin{tabular}{|c|c|c|}
\hline \multirow{3}{*}{ 규 } & & Laba Bersih \\
\hline & Total & 19.715 .815 .388 \\
\hline & Mean & $1.642 .984 .615,66$ \\
\hline \multirow{2}{*}{ ㄱ. } & Total & 12.232 .260 .126 \\
\hline & Mean & 1.019.355.010,5 \\
\hline \multirow{2}{*}{ 으으 } & Total & $10.429 .322,879$ \\
\hline & Mean & $869.110 .239,91$ \\
\hline
\end{tabular}

Dengan melihat gambaran pada tabel 4 dapat dipaparkan hal-hal sebagai berikut:

a. Pada tahun 2008 perusahaan mampu meraih laba bersih Rp 19.715.815.388,00 atau sekitar $\mathrm{Rp}$ 1.642.984.615,66 tiap bulannya. Sedangkan total aktiva atau asset yang dimiliki oleh perusahaan sebagai harta perusahaan yang dapat dipergunakan sebagai modal kerja perusahaan pada tahun 2008 adalah sebesar $\mathrm{Rp}$ 34.450.789.898,40 atau rata-rata sebesar Rp 2.870.889.258,2. Dengan demikian rasio profitabilitas perusahaan pada tahun 2008 adalah 57,23 .

b. Pada tahun 2009 perusahaan mampu memperoleh laba bersih sebesar Rp 12.232.260.125,00 atau rata-rata sebesar Rp 1.019.355.010,50. Sedangkan total aktiva harta kekayaan perusahaan yang dapat dipergunakan sebagai modal kerja perusahaan pada tahun 2009 adalah sebesar Rp 25.709.281.924,40 atau rata-rata $\mathrm{Rp}$ 2.142.440.160,30. Dengan demikian pilitas) Toko Iqra Tahun 2008-2010

Total aktiva Rasio Mean

34.450.789.898,4

$2.870 .899 .158,2$

25.709.281.924,4

$2.142 .440 .160,36$

57,23

$22.608 .775 .247,8$

1.884.064.603,98

47,58 กें

46,13 tahun 2009 adalah 47,58.

c. Pada tahun 2010 perusahaan mampu meraih laba sebesar Rp 10.429.322.879,00 atau rata-rata $\mathrm{Rp}$ 869.110.239,916. Sedangkan total aktiva atau asset yang dimiliki oleh perusahaan sebagai harta kekayaan perusahaan yang dapat dipergunakan sebagai modal kerja perusahaan pada tahun 2010 adalah sebesar Rp 22.608.775.247,80 atau rata-ratanya sebesar Rp 1.884.064.603,98. Dengan demikian rasio profitabilitas perusahaan pada tahun 2008 adalah 46,13 .

\section{Analisis Asumsi Klasik Variable Penelitian}

a. Autokorelasi

Autokorelasi adalah pengujian untuk mendeteksi tingkat keeratan suatu hubungan antar variable independen/ bebas. Asumsi autokorelasi ini didefinisikan sebagai terjadinya korelasi antara dua pengamatan yang memungkinkan munculnya suatu data dipengaruhi oleh data sebelumnya. Adanya 
suatu korelasi bertentangan dengan salah satu asumsi acaknya. Artinya jika ada autokorelasi maka dapat dikatakan bahwa data yang diperoleh tersebut kurang akurat. Untuk mengetahui ada atau tidaknya autokorelasi digunakan uji Durbin Watson yang bisa dilihat dari hasil uji regresi berganda.

Kriteria penerimaan dalam uji Durbin Watson adalah sebagai berikut :

a. Dalam pengujian tidak terjadi autokorelasi apabila DW diatas, DU (batas atas) yang diperkenankan dan regresi berganda bisa dilakukan.

b. Terjadi autokorelasi apabila nilai DW dibawah, DL (batas bawah) yang diperkenankan, dengan demikian regresi berganda tidak bisa dilakukan.

c. Apabila nilai DW diantara DL dan DU maka pengujian menjadi bias dan regresi berganda apabila tetap dilakukan akan menghasilkan pemahaman yang menyesatkan.

\section{b. Multi Kolinearitas}

Multikol adalah suatu keadaan yang mengambarkan hubungan antara berbagai variable baik itu antara variable bebas/independen maupun antara variable bebas dengan variable dependent/tergantung. Suatu keadaan dikatakan multikol jika hubungan (korelasi) yang tinggi diantara variable yang ada pada sutau obyek penelitian. Secara statistik nilai korelasi yang diperkenankan adalah dibawah taraf signifikan (a) dan nilai VIF $<10$. Analisis regresi berganda akan dapat dilanjutkan apabila dalam hasil uji ini surut atau sebagian besar variable penelitian tidak dalam kondisi multikol. Dalam penelitian ini, nilai-nilai relakonship dapat dilihat pada tabel 5 dan tabel 6 berikut ini :

\begin{tabular}{ccccc}
\multicolumn{5}{c}{ Tabel 5 Nilai korelasi } \\
\hline & $\mathrm{Y}$ & $\mathrm{X}_{1}$ & $\mathrm{X}_{2}$ & $\mathrm{X}_{3}$ \\
\hline $\mathrm{Y}$ & 1,000 & 0,266 & - & $-0,626$ \\
$\mathrm{X}_{1}$ & 0,058 & 0,058 & 0,092 & 0,013 \\
$\mathrm{X}_{2}$ & 0,092 & 0,092 & - & 0,001 \\
$\mathrm{X}_{3}$ & 0,000 & 0,013 & 0,001 & - \\
\hline
\end{tabular}

Tabel 6. Nilai VIF

\begin{tabular}{cccc}
\hline Variable bebas & $\begin{array}{c}\text { VIF } \\
\text { Hitung }\end{array}$ & $\begin{array}{c}\text { VIF } \\
\text { Standar }\end{array}$ & Keterangan \\
\hline $\mathrm{X}_{1}$ & 1,163 & $<10$ & $\begin{array}{l}\text { Tidak multi } \\
\text { kolinearitas }\end{array}$ \\
$\mathrm{X}_{2}$ & 1,369 & $<10$ & $\begin{array}{l}\text { Tidak multi } \\
\text { kolinearitas } \\
\text { Tidak multi } \\
\text { kolinearitas }\end{array}$ \\
\hline
\end{tabular}

Dengan melihat tabel 5 tersebut nampak jika semua variable penelitian mempunyai nilai korelasi dibawah taraf signifikansi yang diperkenankan, yaitu dalam penelitian ini sebesar 0,005 atau $\propto=$
5\%. Sedangkan jika mengacu pada tabel 6 nampak jika semua variable bebas dalam penelitian ini mempunyai nilai VIF $<10$ yang berarti bahwa tidak ada satupun variable bebas yang memiliki keterkaitan antara satu dengan yang lainnya. Makna 
yang terkandung adalah bahwa penelitian ini layak untuk dilanjutkan pada analisis regresi berganda.

\section{c. Heteros Kedastisitas}

Pengujian asumsi klasik heteros kedastisitas dilakukan untuk melihat ada tidaknya data-data atau variable-variabel penelitian yang homogeny. Heterogenitas data variable akan mengakibatkan koefesien regresi yang efisien menjadi tidak efisien, sehingga akan berdampak pada hasil penelitian yang bias dan menyesatkan pemahaman dan berakibat pada salah satu penarikan hipotesis penelitian. Suatu data obyek penelitian dikatakan homogeny apabila nilai $\mathrm{R}>0,1$. Apabila suatu data bersifat homogen, maka analisis dan olah data dapat dilanjutkan analisis regresi berganda. Pada penelitian ini hasil uji heteros kedastisitas dapat dilihat pada tabel 7 berikut ini :

Tabel 7. Hasil Uji Heteros Kedastisitas

\begin{tabular}{ccccc}
\hline $\mathrm{R}$ & R square & Adjested R. Square & Standar uji & Keterangan \\
\hline 0,637 & 0,406 & 0,351 & $\mathrm{R}>0,1$ & $\begin{array}{c}\text { Tidak heteros } \\
\text { kedastisitas }\end{array}$ \\
\hline
\end{tabular}

Dengan mengacu pada tabel 7 tersebut nampak jika nilai $\mathrm{R}$ dalam penelitian ini berada pada nilai 0,637 yang berarti diatas standar uji $\mathrm{R}>0,1$. Makna yang terkandung adalah dalam penelitian ini semua data dan variable penelitian tidak terjadi heterogen, sehingga pengujian dapat dilanjutkan pada uji regresi berganda.

\section{d. Analisis Regresi Berganda}

\section{Hasil uji keseluruhan}

Analisis regresi berganda dalam penelitian ini memiliki variable bebas lebih dari satu, yaitu : $X_{1}, X_{2}$, dan $X_{3}$. Perlu diketahui bahwa dalam analisis ini terdapat beberapa alat uji atau kriteria pengolahan data regresi, yang semua alat uji tersebut merupakan bagian dari analisis regresi berganda. Sebelum melakukan analisis perlu sekali lagi kita mengetahui apakah variable-variabel bebas tersebut mempunyai pengaruh yang besar atau kecil terhadap variable terikatnya, yang dalam penelitian ini adalah profitabilitas (kemampuan pencapaian laba). Untuk itu akan dilakukan analisis secara bertahap terhadap variable bebasnya, kemungkinan besaran pengaruh yang signifikan masingmasing variable bebas baik itu variable kas $\left(\mathrm{X}_{1}\right)$, variable piutang $\left(\mathrm{X}_{2}\right)$, serta persediaan $\left(\mathrm{X}_{3}\right)$ terhadap variable laba $(\mathrm{Y})$. Selain itu juga nanti akan diketahui dari kinerja variable bebas tersebut, variable yang mempunyai pengaruh paling dominan terhadap variable laba. Jadi sebenarnya dalam analisis regresi berganda tersebut tidak hanya memberikan informasi berapa besaran jumlah pengaruh variable yang masuk ke dalam model, tetapi sekaligus nilai yang ada masing-masing pada masing-masing variable bebas. Dalam penelitian ini hasil uji model secara keseluruhan tampak pada tabel 8 berikut ini

Tabel 8 Analisi Uji Keseluruhan

\begin{tabular}{|c|c|c|c|c|c|c|c|c|c|c|}
\hline Model & $\mathrm{R}$ & $\begin{array}{c}\mathrm{K} \\
\text { Square }\end{array}$ & $\begin{array}{l}\text { Adjusted R } \\
\text { Square }\end{array}$ & $\begin{array}{c}\text { Std Eror } \\
\text { of the } \\
\text { estimate }\end{array}$ & $\begin{array}{c}\text { R } \\
\text { Square } \\
\text { Change }\end{array}$ & $\begin{array}{c}\mathrm{F} \\
\text { Change }\end{array}$ & $\mathrm{Df}_{1}$ & $\mathrm{Df}_{2}$ & $\begin{array}{c}\text { Sigf } \\
\text { change }\end{array}$ & $\begin{array}{l}\text { Durbin } \\
\text { Watson }\end{array}$ \\
\hline 1 & 0,637 & 0,406 & 0,351 & 0,094220 & 0,406 & 7,298 & 3 & 32 & 0,001 & \\
\hline & mpak & $\begin{array}{ll}\text { gan } m \\
\text { jahwa }\end{array}$ & $\begin{array}{ll}\text { ihat } & \text { pada } \\
\text { tiga } & \text { varial }\end{array}$ & $\begin{array}{l}\text { tabel } 8 \\
\text { le bebas }\end{array}$ & & bail & 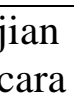 & $\begin{array}{l}\text { ini } \\
\text { jelas }\end{array}$ & $\begin{array}{l}\text { nemb } \\
\text { abel }\end{array}$ & $\begin{array}{l}\text { an nilai } \\
\text { halisa uji }\end{array}$ \\
\hline
\end{tabular}

50 Analisis Pengaruh Manajemen Modal .... 
keseluruhan tersebut memberikan informasi mengenai $\mathrm{k}$ square atau koefisien determinan sebesar 0,406. Hal tersebut bermakna bahwa pengaruh dari ketiga variable bebas terhadap vaariabel terikat sebesar $40,6 \%$ dengan tingkat signifikan 0,001. Hasil ini memberikan estimasi kesalahan yang masih dibawah taraf signifikan (a) 5\% atau 0,005. Makna yang dapat diambil adalah secara keseluruhan ketiga variable bebas memberikan pengaruh yang positif terhadap pencapaian sebesar $40,6 \%$ atau sisanya dipengaruhi oleh variable yang lain diluar variable penelitian.

2. Uji F (Simultan)
Untuk mengetahui besaran pengaruh masing-masing variable kas $\left(\mathrm{X}_{1}\right)$, variable piutang $\left(\mathrm{X}_{2}\right)$, serta variabel persediaan $\left(\mathrm{X}_{3}\right)$ terhadap variable laba $(\mathrm{Y})$ dilakukan dengan menggunakan uji $F$ (Simultan atau Uji Serentak). Berkenaan dengan pengujian secara serentak atau simultan ini, maka hipotesis yang akan di uji akan dapat dinyatakan positif apabila nilai $\mathrm{F}$ hitung lebih besar daripada nilai $\mathrm{F}$ tabel (Standar) dan tingkat signifikasi dibawah taraf signifikan yang disyaratkan $5 \%$ atau a $=0,005$. Hasil uji $\mathrm{F}$ ini dalam penelitian ini dapat dilihat pada tabel 9.berikut ini:

Tabel 9. Hasil Uji F (simultan)

\begin{tabular}{cccccc}
\hline Model & $\begin{array}{c}\text { Sum of } \\
\text { squares }\end{array}$ & df & Mean Squares & F & Sig \\
\hline \multirow{2}{*}{ Regression } & 0,194 & 3 & 0,065 & 7,298 & 0,001 \\
& 0,284 & 32 & 0,009 & & \\
& 0,478 & 35 & & &
\end{tabular}

Residual

Total

Dengan melihat pada tabel 9 tersebut nampak nilai $\mathrm{F}$ hitung sebesar 7,289 dengan tingkat signifikasi 0,001 atau sebesar $1 \%$. Pada sisi lain nilai $\mathrm{F}$ tabel dengan variable bebas sebanyak 3 variabel dan sampel sejumlah 36 obyek pengamatan adalah sebesar 2,342. Jika dibandingkan maka dapat dinyatakan bawa nilai $\mathrm{F}$ hitung $>$ nilai $\mathrm{F}$ tabel yang berarti secara simultan ketiga variable bebas mempunyai pengaruh yang signifikan terhadap laba. Pemahaman yang dapat diambil dari hasil uji ini adalah adanya hipotesis pertama (Hipotesis I) yang menyatakan bahwa variable kas $\left(\mathrm{X}_{1}\right)$, variable piutang $\left(\mathrm{X}_{2}\right)$ serta variable persediaan $\left(\mathrm{X}_{3}\right)$ secara bersama-sama mempunyai pengaruh yang signifikan terhadap variable laba $(\mathrm{Y})$ dapat diterima dan terbukti.

\section{Hasil Uji t (Parsial)}

Uji t (Parsial) ini dilakukan untuk mengetahui besaran pengaruh masingmasing variable bebas terhadap variable terikat secara signifikan. Selain itu juga dengan melakukan uji $t$ ini, dalam penelitian ini akan dapat dilakukan pengujian hipotesis kedua (Hipotesis 2) yaitu secara terpisah (Parsial) variabelvariabel kas $\left(\mathrm{X}_{1}\right)$, variable piutang $\left(\mathrm{X}_{2}\right)$ serta variable persediaan $\left(\mathrm{X}_{3}\right)$ mempunyai pengaruh yang signifikan terhadap variable laba (Y). Uji $\mathrm{t}$ akan dinyatakan memberikan hasil yang positif pada variable terikat apabila nilai t hitung > nilai t tabel dengan tingkat signifikasi dibawah taraf signifikan yang disyaratkan yaitu 5\% atau sebesar 0,005. Dalam penelitian ini hasil uji t (Parsial) dapat dilihat pada tabel 10 berikut ini : 
Tabel.10 Hasil Uji t (parsial)

\begin{tabular}{|c|c|c|c|c|c|}
\hline \multirow[b]{2}{*}{ Variable } & \multicolumn{2}{|c|}{ Unstandardized Coefficients } & \multirow{2}{*}{$\begin{array}{l}\text { Unstandardized } \\
\text { Coefficients } \\
\text { Beta }\end{array}$} & \multirow[b]{2}{*}{$\mathrm{t}$} & \multirow[b]{2}{*}{ Sig } \\
\hline & B & Std Error & & & \\
\hline 1 (constant) & 0,498 & 0,139 & & 3,575 & 0,001 \\
\hline Kas & 0,000 & 0,001 & 0,043 & 0,295 & 0,770 \\
\hline Piutang & 0,011 & 0,013 & 0,136 & 0,852 & 0,401 \\
\hline Persediaan & $-0,531$ & 0,131 & $-0,680$ & $-4,064$ & 0,000 \\
\hline
\end{tabular}
tersebut nampak bahwa secara keseluruhan semua variable bebas penelitian ini yaitu kas $\left(\mathrm{X}_{1}\right)$, piutang $\left(\mathrm{X}_{2}\right)$, serta persediaan $\left(X_{3}\right)$ secara terpisah tidak berpengaruh Tabel 11..Kriteria Penurunan Uji t

\begin{tabular}{|c|c|c|c|c|c|}
\hline Variable Bebas & t hitung & $\mathrm{t}$ tabel & Sig & $\mathrm{a}$ & Keterangan \\
\hline $\mathrm{X}_{1}$ & 0,295 & 2,342 & 0,770 & 0,05 & $\begin{array}{l}\text { Tidak berpengaruh } \\
\text { signifikan }\end{array}$ \\
\hline $\mathrm{X}_{2}$ & 0,852 & 2,342 & 0,401 & 0,05 & $\begin{array}{l}\text { Tidak berpengaruh } \\
\text { signifikan }\end{array}$ \\
\hline $\mathrm{X}_{3}$ & $-0,064$ & 2,342 & 0,000 & 0,05 & $\begin{array}{l}\text { Tidak berpengaruh } \\
\text { signifikan }\end{array}$ \\
\hline
\end{tabular}

Dengan berdasarkan pada tabel 11 maka besaran koefesien masing-masing variable bebas terhadap variable terikat dapat dilihat dengan rumus berikut ini : $\mathrm{Y}=0,498+0,000 \mathrm{X}_{1}+0,011 \mathrm{X}_{2}+(-$ 0,531) $\mathrm{X}_{3}+$ ei

Pemahaman yang dapat diambil dari rumus tersebut dapat dipaparkan sebagai berikut:

a) Variable kas $\left(\mathrm{X}_{1}\right)$, memberikan pengaruh terhadap pencapaian laba $(\mathrm{Y})$ sebesar 0, 000.

b) Variable piutang $\left(\mathrm{X}_{2}\right)$, memberikan pengaruh terhadap pencapaian laba $(\mathrm{Y})$ sebesar 0,011, jika dibandingkan dengan variable lainnya.

c) Variable persediaan $\left(X_{3}\right)$, memberikan pengaruh terhadap pencapaian laba $(\mathrm{Y})$ sebesar $-0,531$.

Adapun kontribusi pengaruh masing-masing variable bebas terhadap variable terikat sebagaimana tampak pada tabel 11 dapat dijabarkan sebagai berikut: penelitian ini sebagai variable terikat $(Y)$.

Kesimpulan tersebut ditarik berdasarkan pada kriteria uji t yang tampak pada tabel 11 berikut ini: 
bahwa secara terpisah (Parsial) variabelvariabel kas $\left(\mathrm{X}_{1}\right)$, piutang $\left(\mathrm{X}_{2}\right)$ dan persediaan $\left(\mathrm{X}_{3}\right)$ tidak terbukti mempunyai pengaruh secara partial.

\section{Uji Dominasi}

Uji Dominasi dilakukan untuk menemukan dan menentukan faktor atau variable-variabel bebas dari suatu obyek penelitian yang mempunyai dominasi dalam mempengaruhi variable terikatnya. Makna dominasi dalam mempengaruhi variable terikatnya, makna dominasi disini adalah variable yang tergolong variable dominan hendaknya selalu menjadi prioritas perusahaan dalam mempromosikan keberadaannya dalam penetapan tujuan serta target operasional.Uji Dominasi dilakukan dengan membandingkan antara korelasi per subsystem terhadap keberadaan variable terikatnya. Dalam penelitian ini hasil dominasi terlihat dalam tabel 12 .

Tabel 12. Hasil uji dominasi

\begin{tabular}{ccc}
\hline $\begin{array}{c}\text { Variable } \\
\text { bebas }\end{array}$ & Standardized Coefficient Beta & Keterangan \\
$\mathrm{X}_{1}$ & 0,043 & Dominan 2 \\
$\mathrm{X}_{2}$ & 0,136 & Dominan 1 \\
$\mathrm{X}_{3}$ & $-0,680$ & Dominan 3 \\
\hline
\end{tabular}

Dengan mengacu pada tabel 12 maka hendaknya mempertimbangkan dapat dijelaskan hal-hal sebagai berikut :

a) Variable $X_{1}$ yaitu variable kas faktor-faktor sebagai berikut :

memiliki nilai 0,043 dalam kemampuan pencapain laba toko Iqra.

b) Variable $X_{2}$ yaitu variable piutang ternyata memiliki nilai 0,136 kontribusi dominan dalam upaya pencapaian laba toko Iqra.

c) Variable $X_{3}$ yaitu variable persediaan merupakan faktor yang paling rendah dominannya dalam upaya pencapaian laba pada toko Iqra.

Hasil uji dominasi tersebut ternyata menolak hipotesis ketiga (Hipotesis 3) yaitu bahwa persediaan mempunyai pengaruh dominan diantara variable kas $\left(\mathrm{X}_{1}\right)$, piutang $\left(\mathrm{X}_{2}\right)$ secara signifikan terhadap laba toko Iqra.

\section{B. Pembahasan}

Setelah melakukan semua analisis dan olah data maka dapat dibuktikan apabila toko Iqra ingin meningkatkan kemampuan pencapaian laba usahanya,
1. Kas

Pemilik usaha harus selalu memperhatikan posisi kas dalam laporan keuangannya. Secara empiris terbukti bahwa kas merupakan faktor kedua yang menentukan besar kecilnya kemampuan pencapaian laba. Oleh karena itu harus selalu dilakukan upaya-upaya pengelolaan kas dan menambah adanya aliran kas masuk yang didapatkan dari peningkatan penjualan barang. Dalam penelitian nampak jika pada tahun 2008 akumulasi kas pada tahun 2008 sebesar Rp 233.096.950,00 atau $\mathrm{Rp} 19.424 .745,83$ perbulan. Dan pada tahun 2009 akumulasi kas sebesar Rp 216.672.400,00 atau Rp 18.056.033,00 perbulannya, terjadi penurunan Rp 1.368.713,00 perbulannya. Sedangkan pada tahun 2010 akumulasi kas sebesar Rp 255.795.000,00 atau Rp 21.316.250,00 perbulannya, terjadi kenaikan Rp 3.260.217,00 dibanding tahun sebelumnya yaitu tahun 2009. Jika keberadaan kas dari tahun ke tahun dapat 
dipertahankan atau dinaikkan akan dapat mempengaruhi kelancaran operasioanal perusahaan yang dijalankan.

\section{Piutang}

Piutang bagi perusahaan juga perlu ditingkatkan pengelolaannya, karena dari hasil penelitian variable ini paling dominan dan sangat berpotensi untuk memperbesar laba berusahaan. Untuk itu pengelolaan dan manajemen piutang perlu diperlakukan prinsip-prinsip kehati-hatian dan diusahakan secepatnya piutang atau perputaran piutang dijadikan uang tunai. Sehingga tidak mengganggu Cash Flow perusahaan. Dalam penelitian nampak akumulasi piutang tahun 2008 sebesar Rp 3.943.156.960,20 atau rata-rata perbulan Rp 328.596.413,35. Pada tahun 2009 akumulasi piutang sebesar Rp 2.446.501.999,20 atau $\mathrm{Rp}$ 20.387.516,6 rata-rata perbulannya. Sedangkan tahun 2010 sebesar Rp 1.070.953.372,80 atau sebesar $\mathrm{Rp}$ $89.241 .114,3166$ rata-rata perbulannya. Dari gambaran tersebut meskipun piutang mengalami penurunan tiap tahunnya namun dalam penelitian tersebut masih memberikan kontribusi pencapaian laba perusahaan. Jika dikelola dengan baik dan perputaran piutang menjadi kas tunai dijaga dengan baik. Maka akan meningkatkan kemampuan pencapaian laba. Hal ini pun bermakna jika perusahaan mampu untuk selalu meningkatkan piutang yang dimasa depan dapat memaksimalkan aliran kas masuk berupa pendapatan operasional sehingga diharapkan dimasa mendatang tercapai laba yang signifikan. Dengan demikian penelitian ini pada intinya mendukung teori yang dikemukakan oleh Syahrial dan juga Sartono, yaitu jika besaran piutang yang terjadi pada suatu perusahaan akan dapat menimbulkan besaran pendapatan dan profitabilitas yang signifikan dimasa mendatang.

\section{Persediaan}

Persediaan dari hasil penelitian yang dibuktikan dengan analisis mempunyai nilai dominasi yang kecil. Namun demikian persediaan merupakan asset perusahaan, perlu pengelolaan, perencanaan dan pengendalian. Perputaran persediaan atau keluar masuknya barang perlu mendapatkan perhatian serius oleh pemilik usaha. Tingginya persediaan yang tidak diimbangi perputaran, persediaan akan berdampak pada operasional perusahaan, terutama berdampak pada Cost atau berbagai biaya dimasukkannya biaya gudang, biaya pemeliharaan, resiko kadaluarsa, resiko kerusakan dan berubahnya selera masyarakat terhadap suatu barang. Pada tahun 2008 jumlah atau akumulasi persediaan sebesar Rp 19.715.815.383,00 atau rata-rata perbulannya $\mathrm{Rp}$ 1.642.984.615,25. Pada tahun 2009 sebesar Rp 12.232.260.026,00 atau rata-rata perbulannya $\mathrm{Rp}$ 1.019.355.002,16 terjadi penurunan sebesar Rp 623.629.613,09 dibanding tahun 2008. Sedangkan pada tahun 2010 akumulasi persediaan Rp 10.714.523.879,00 atau rata-rata perbulannya $\mathrm{Rp} 892.876 .989,916$, terjadi penurunan juga dibanding tahun sebelumnya sebesar Rp 126.478.012,25 jika dibanding tahun 2009. Melihat kondisi yang ada, jika perusahaan mampu merencanakan, mengelola, mengendalikan maka variable persediaan mampu meningkatkan kemampuan pencapaian laba perusahaan dimasa-masa akan datang.

\section{Kemampuan Pencapaian Laba (Profitabilitas)}

Laba merupakan tujuan utama perusahaan dalam sikap operasionalnya. Jika dalam kegiatan usahanya perusahaan tidak mampu mencapai laba yang 
diinginkan, maka dapat dikatakan jika kinerja perusahaan tersebut adalah buruk. Dalam penelitian ini didapatkan data jika selama 2008 bahwa toko Iqra mampu meraih laba $R p$ 3.490.452.169,00 atau ratarata perbulannya $\mathrm{Rp} 290.871 .014,083,00$. Sedangkan total asset yang dimiliki oleh perusahaan sebagai harta kekayaan perusahaan yang dapat dipergunakan sebagai modal kerja perusahaan pada tahun 2008 adalah sebesar Rp 34.450.789.898,5 atau rata-rata perbulannya $\mathrm{Rp}$ 2.870.899.158,20. Dengan demikian rasio profitabilitas perusahaan pada tahun 2008 adalah sebesar Rp 10,132. Dan pada tahun 2009 perusahaan mampu meraih laba sebesar Rp 1.499.449.870,34 atau rata-rata perbulannya $\mathrm{Rp} \quad 124.954 .072,528$. Sedangkan rata aktiva atau harta perusahaan yang dapat dipakai sebagai modal kerja adalah sebesar Rp 25.709.281.925,20 atau rata-rata perbulannya sebesar Rp 2.142.440.160,43. Dengan demikian rasio profitabilitas perusahaan pada tahun $2009 \mathrm{Rp} 5,832$. Pada tahun 2010 perusahaan mampu memperoleh laba sebesar Rp 582.666.688,31 atau rata-rata perbulannya Rp 48.555.557,3591. Sedangkan total asset yang dimiliki perusahaan yang dapat dipergunakan sebagai modal kerja perusahaan sebesar $\mathrm{Rp}$ 22.608.775.247,8 atau rata-rata perbulannya sebesar $\mathrm{Rp}$ 1.884.064.603,98.

\section{KESIMPULAN}

Dari hasil analisis yang telah dilakukan pada bab sebelumnya dapat dijelaskan bahwa penelitian ini berfokus pada faktor-faktor yang mempengaruhi pencapaian laba masa depan. Hasil uji dan olah data menerangkan hal-hal sebagai berikut :

1. Hipotesis pertama (Hipotesis 1) yang mengatakan bahwa variable kas $\left(\mathrm{X}_{1}\right)$, variable piutang $\left(\mathrm{X}_{2}\right)$ serta variable persediaan $\left(\mathrm{X}_{3}\right)$ secara bersama-sama mempunyai pengaruh terhadap variable laba (Y) dapat dibuktikan pada Uji F sehingga dapat diterima dan terbukti.Penilaian keyakinan hipotesis tersebut didasarkan pada hasil uji bahwa nilai $\mathrm{F}$ hitung adalah sebesar 7,298 dengan tingkat signifikan 0,001 atau sebesar $0,1 \%$.Pada sisi lain nilai $\mathrm{F}$ tabel dengan variable bebas sebanyak 3 variabel dan sampel sejumlah 36 obyek pengamatan adalah 2,342. Jika dibandingkan maka dinyatakan bahwa nilai $\mathrm{F}$ hitung $>$ nilai $\mathrm{F}$ tabel yang berarti secara simultan ketiga variable bebas mempunyai pengaruh yang signifikan terhadap laba.

2. Hipotesis kedua (Hipotesis 2) yang mengatakan bahwa secara terpisah (Parsial) variable-variabel kas $\left(\mathrm{X}_{1}\right)$, piutang $\left(\mathrm{X}_{2}\right)$ dan persediaan $\left(\mathrm{X}_{3}\right)$ tidak terbukti memberikan pengaruh secara parsial terhadap variable (Y) pencapaian laba. Penarikan keyakinan hipotesis tersebut didasarkan pada halhal sebagai berikut :Variable kas $\left(\mathrm{X}_{1}\right)$, mempunyai nilai 0,000 secara parsial variable ini tidak terbukti memberikan pengaruh terhadap variable $(\mathrm{Y})$ pencapaian laba. Variable piutang $\left(\mathrm{X}_{2}\right)$, memberikan pengaruh terhadap pencapaian laba (Y) sebesar 0,011.

3. Variabel persediaan $\left(\mathrm{X}_{3}\right)$, mempunyai nilai $-0,531$ terhadap pencapain laba. Variable kas $\left(\mathrm{X}_{1}\right)$ memberikan pengaruh 0,000 terhadap pencapaian laba (Y). Pengertian yang terkandung adalah apabila toko Iqra mengalami peningkatan kas 0,000 atau 0\% dari tahun lalu, maka perlu usaha peningkatan penjualan supaya kas perusahaan lebih meningkat. Variable piutang memberikan pengaruh terhadap laba (Y) sebesar 0,011 atau 
1,1\%. Makna yang terkandung adalah apabila perusahaan menambah jumlah piutangnya sampai sebesar $1,1 \%$, maka pada saat dan periode yang sama tersebut membuka peluang bagi toko Iqra untuk meningkatkan laba sampai $100 \%$ dibandingkan dengan periode sebelumnya.Variable persediaan $\left(\mathrm{X}_{3}\right)$ 0,531 menyatakan bahwa setiap penambahan (karena tanda -) akan mengurangi laba sebesar $-0,531$.

4. Hipotesis ketiga (Hipotesis 3) yaitu bahwa persediaan mempunyai pengaruh dominan diantara variablevariabel kas $\left(\mathrm{X}_{1}\right)$, piutang $\left(\mathrm{X}_{2}\right)$ terhadap kemampuan pencapaian laba ternyata tidak terbukti. Penolakan hipotesis ini berdasarkan hasil uji sebagai berikut Variable $\left(\mathrm{X}_{1}\right)$, yaitu variable kas memiliki nilai yang dominan kedua setelah piutang dalam upaya pencapaian laba. Variable $\left(\mathrm{X}_{2}\right)$ yaitu ternyata memiliki nilai yang dominan dalam upaya kemampuan pencapaian laba pada toko Iqra. Variable $\left(\mathrm{X}_{3}\right)$ yaitu variable persediaan yang merupakan faktor yang paling rendah dominannya dalam kemampuan pencapaian laba pada toko Iqra.

\section{DAFTAR PUSTAKA}

Suharsimi Arikunto, 1998. Prosedur Penelitian Suatu Pendekatan Praktek, Edisi Revisi IV. Penerbit RINEKA CIPTA.

Sugiyono, 2003. Metode Penelitian Bisnis, Edisi Kelima, Penerbit Ikatan Penerbit Indonesia (IKAPI).

Burhan Murgiyantoro, Gunawan, Marzuki, Statistik Terapan, 2002. Edisi kedua (Revisi), Gajah Mada Universtiy Press.
Marheany Djumadi, 2010. Metodologi Riset, STIE “ABI” Surabaya.

Algifari, 1997. Analisis Statistik untuk Bisnis, Edisi pertama, Penerbit BPPE UGM, Yogyakarta.

Belkawuni, Achmed Riahi, 2009. Teori Akuntansi, Edisi Pertama, Jilid Dua, Terjemahan Marwata dkk, Penerbit Salemba Empat, Jakarta.

Djarwanto, Ps dan Pangestu Subagyo, 1998, Statistik Induktif Edisi Keempat, Penerbit BPPE, Yogyakarta.

Eko Widodo Lo, 2001. Rasio Keuangan Untuk Mengukur Asosiasi Likuiditas, Strimilar Modal, dan Kualitas Aktiva dengan Profitabilitas.

Ikatan Akuntansi Indonesia, 2002. Standar Akuntansi Indonesia, Penerbit Salemba Empat, Jakarta.

J. Fred. Weston dan Eugene F. Bringham, 1998. Dasar-Dasar Manajemen Keuangan, Edisi Kesembilan, Jilid I, Penerbit Erlangga, Jakarta.

Munawir, S. 1992. Analisa Laporan Keuangan, Edisi Keempat, Cetakan Ketiga. Penerbit Liberty, Yogyakarta.

Sartono, Agus, 2001. Manajemen Keuangan Teori dan Aplikasi Edisi Keempat. Penerbit BPFZ, Yogyakarta.

Syahrul, SE., Muhammad Afdi Nizar, SE. 2000, Kamus Akuntansi, Penerbit Citra Harta Prima. 